\title{
Role and Strategy of Hotel Public Relations in Returning Guests After Selat Sunda Tsunami
}

\author{
Widya Nur Bhakti Pertiwi ${ }^{1, *}$, Diqbal Satyanegara ${ }^{2}$, Asmi Ayuning Hidayah ${ }^{3}$ \\ [Faculty of Economic and Business, Universitas Sultan Ageng Tirtayasa, Serang, 42112, \\ widya.nbp@untirta.ac.id]
}

Received: $14 / 04 / 2020$.

Reviewed: $21 / 04 / 2020$.

Published: 31/08/2020.

Copyright $\odot 2020$ by the author (et al) and Jurnal Sosial Humaniora (JSH)

*This work is licensed under the Creative

Commons Attribution International License (CC

BY 4.0).

http://creativecommons.org/licenses/by/4.0/

\begin{abstract}
Subject Area: Business
Abstract

The purpose of this research is to figure out the role of public relations, as well as the strategy of public relations in the effort to improve the hotel occupancy rate in Anyer, Serang, Banten after the Selat Sunda tsunami. The methodology used in this study is a qualitative descriptive approach, with in-depth interviews to collect data. This method of data collection is commenced by interviews with hotel managers in Anyer. The samples of this research are five hotels in Anyer Serang, Banten, to represent their respective classes: five-star hotels, four-stars, three-star, and budget hotels. The results of this study show that the PR of the hotels in Anyer have done their role well, but they have not been able to increase the maximum number of room occupancy of the hotels in Anyer, Serang, Banten.
\end{abstract}

Keywords: hotels business; public relation; promotion strategy

\section{Introduction}

Tourism is one of the largest sectors in the world as an economic generator, but it is very prone to disasters, either natural or man-made (Zaenuri, 2014). Tourism is a journey from one place to another, being temporary, conducted individually or in groups as an effort to seek balance or harmony with the environment in the social dimension, culture, nature, and science (Kurniasari, 2017). Thus, tourism is a process of perroad while individuals or groups with the aim of seeking a balance of life.

Tourism is all tourism activities done by tourists with the facilities and supporting infrastructure provided by the tourist stakeholders. The most important element in the development of tourism is the attraction of tourist attractions (Wilopo \& Hakim, 2017). According to Henderson (1999), tourism is an industry that is consistently haunted by crisis and disaster, it appears to be very sensitive and fragile because it is easily influenced by changes and incidents around (Zaenuri, 2014). Natural disasters that frequent Indonesia's tourist destinations become a series of events that create high levels of uncertainty and threats (Kurniasari, 2017).

Indonesia is the site of three plates, namely Eurasia, Australia, and Pacific. Activities from the plate resulted in Indonesia becoming prone to earthquake. Indonesia is also an island country that is two-by-one, 
the sea makes the earthquake potentially tsunami (Rusli, Irjan, \& Rudyanto, 2010). Many areas need to be aware of the tsunami.

Serang is one of the eight districts in Banten province. Located at the western end of the Java Sea. The area of Serang spreads for 1,467.35 KM2 and it consists of 29 sub-districts. It borders with the Sea of Java along the coast to the north, Tangerang regency to the east, Cilegon City and Sunda Strait to the west, and Lebak and Pandeglang to the south.

Its Sunda Strait border gives Serang many beautiful beaches. The coastal tourism sites are the most popular tourist destinations in Serang. $43 \%$ of the tourist attractions in Serang are beaches. Most of the tourist visiting Serang choose the beaches as their main destination.

The tsunami triggered by the volcanic earthquake hit Banten and Lampung. The worst impacted areas are in the tourism area of Anyer and Tanjung Lesung. It is the main area of the Serang Regency. In addition to causing many casualties, the disaster also led to the drastically decreasing number of tourists visiting Anyer and Tanjung Lesung after a disaster. The chairman of the Indonesian Hotel Association (PHRI) Banten, Ashok Kumar, expressed that the Selat Sunda tsunami disaster has a big impact on the hospitality business on the West coast of Banten. During the new year, the hotel occupancy only reached $10 \%$, there were even hotels that did not have guests at all.

John E. Marston states that the Public Relation division is planned to design ways of communication to influence the publics significantly (Musyaroffah, 2018). Rex F. Harlow defines PR as public relation, which is a distinctive management function and supports coaching, maintaining the joint line between the organization and the public concerning the communication, understanding, acceptance, and cooperation activities involving problematic management or any problem, and to help management to be able to respond to the public using healthy and ethical research and communication techniques as the primary means (Ruslan, 1998; Sulistyawati \& Pertiwi, 2018).

According to Rosady Ruslan (Sulistyawati \& Pertiwi, 2018), the main roles of public relation include: 1. As the communicator or liaison between an organization or an institution it represents and its audience.

2. Establishing a relationship, which seeks to foster a positive and mutually beneficial relationship with his audience,

3. The support of tourism, namely as a supporter that functions in a tourism organization or company.

4. Forming a corporate image, which means that the role of public relations seeks to create imagery for its organization or institution.

The purpose of this research is to figure out the role of public relations, as well as the strategy of public relations in the effort to improve the hotel occupancy rate in Anyer, Serang, Banten after the Selat Sunda tsunami. The benefits of research are to analyze the role of public relations is sufficient or not, in returning hotel guests after Selat Sunda tsunami. 


\section{Literature Review}

John E. Marston states that the Public Relation division is planned to design ways of communication to influence the publics significantly (Musyaroffah, 2018). Rex F. Harlow defines PR as public relation, which is a distinctive management function and supports coaching, maintaining the joint line between the organization and the public concerning the communication, understanding, acceptance, and cooperation activities involving problematic management or any problem, and to help management to be able to respond to the public using healthy and ethical research and communication techniques as the primary means (Ruslan, 1998; Sulistyawati \& Pertiwi, 2018). The literature identifies that marketing communication must focus on two areas to restore visitor numbers, changing the perceptions and misconceptions of the destination caused by intense media coverage, and restoring visitor confidence in the destination (Prideaux, Coghlan, \& Falco-Mammone, 2008; Scott, Laws, \& Prideaux, 2008; Walters \& Mair, 2012; Nguyen \& Imamura, 2017). Public relations must concern in customer communication for building positive perception in public.

\section{Methodology}

The method used in this research is a qualitative, descriptive method of study. This research only describes the situation or event and does not seek the relationship and does not test hypotheses or make predictions (Rakhmat, 2009). Qualitative descriptive research concentrates on a specific unit of various phenomena. In-depth research and data are taken into consideration in this study.

\section{Research Subjects and Objects}

The subject in this study is the hotels located around the beaches of Anyer, Serang, Banten. The study focuses on Public Relations (PR) and hotel marketers with PR task. While the research object is a role or strategy that is commenced as an effort to increase the number of visits in these hotels post Sunda Strait tsunami.

\section{Research Samples}

The sampling technique in this study is the nonprobability sampling technique, which is a sampling technique that does not provide the same opportunity for any element or member of the population to be selected into a sample. The population for this research is 36 hotels scattered in the Anyer area. The samples are the five hotels representing each class hotels, including:

1. Sol Elite Marbella (5 stars)

2. Hotel Mambruk (4 stars)

3. Patra Hotels (3 stars)

4. Pondok Layung (budget)

5. Green Garden (budget)

\section{The data collection techniques in this study, include:}

It is the process of obtaining information for research purposes by commencing questions to get answers by the interviewer to the informant or the person interviewed, with or without using the interview 
guidelines. It is a method of data collection done in a systematic way to observe and record the research object. It is a data collection instrument to obtain information that supports the analysis and interpretation of data. Documents can be images, writings, or more. The documents can complement the interviews and observation methods.

\section{Data Analysis Methods}

This research uses data analysis with the interactive model term, consisting of three models. Data reduction is interpreted as the electoral process, focusing on the simplification of the data, and the abstracting of the large data transformation arising from the written records in the field (Saebani, 2013). Data presentation involves the steps of organizing the data, namely associating a group of data to another so that all the data analyzed create a unified statement. The researchers implement inductive principles by taking the existing data patterns and or tendencies from the compiled data display into account. The research uses credibility testing to test the validity of data, with the source data triangulation technique.

\section{Result and Discussion}

\section{The role of public relations in Anyer area hotels}

Table 1 Comparison of 5 Public Relations Hotels in Anyer

\begin{tabular}{|c|c|c|c|c|c|}
\hline & Pondok Layung & Soll Elite Marbella & Patra & Green Garden & Mambruk \\
\hline $\begin{array}{l}\text { Job } \\
\text { description } \\
\text { PR in normal }\end{array}$ & \begin{tabular}{|l} 
To \\
communicate \\
hotels \\
promotions \\
To greeting \\
customer by \\
message
\end{tabular} & $\begin{array}{l}\text { - Briefing with team } \\
\text { for evaluation } \\
\text { - Visit corporate } \\
\text { customers } \\
\text { - Message personal } \\
\text { customers } \\
\text { - Greeting customer } \\
\text { in hotels }\end{array}$ & \begin{tabular}{|l} 
Briefing with \\
team for \\
evaluation \\
To \\
communicate \\
hotels \\
promotions \\
Message \\
personal \\
customers \\
\end{tabular} & $\begin{array}{l}\text { Visit corporate } \\
\text { customers } \\
\text { Message } \\
\text { personal } \\
\text { customers }\end{array}$ & $\begin{array}{l}\text { Briefing with team } \\
\text { for evaluation } \\
\text { Visit corporate } \\
\text { customers } \\
\text { - Message personal } \\
\text { customers } \\
\text { - Greeting customer in } \\
\text { hotels }\end{array}$ \\
\hline $\begin{array}{l}\text { Hotel guest in } \\
\text { normal }\end{array}$ & $\begin{array}{ll}\text { - In weekday } \\
20 \%-60 \% \\
\text { - In weekend } \\
85 \%-100 \% \\
\end{array}$ & $\begin{array}{l}\text { - In weekday } 35 \% \text { - } \\
70 \% \\
\text { - In weekend } 90 \% \text { - } \\
100 \% \\
\end{array}$ & $\begin{array}{ll}- & \text { In weekday } \\
- & 25 \%-65 \% \\
- & \text { In weekend } \\
90 \%-100 \% \\
\end{array}$ & $\begin{array}{l}\text { - In weekday } \\
\text { - } 25 \%-65 \% \\
\text { - In weekend } 90 \% \\
-100 \% \\
\end{array}$ & $\begin{array}{l}\text { In weekday } 25 \% \text { - } \\
70 \% \\
\text { - In weekend } 90 \% \text { - } \\
100 \%\end{array}$ \\
\hline $\begin{array}{l}\text { Hotel guest } \\
\text { after tsunami }\end{array}$ & - Only 5\% & - $5 \%-10 \%$ & - $10 \%$ & - $10 \%$ & - $5 \%-10 \%$ \\
\hline $\begin{array}{l}\text { Strategy PR } \\
\text { after tsunami }\end{array}$ & $\begin{array}{l}\text { Coordination } \\
\text { with } \\
\text { government } \\
\text { and media } \\
\text { More often } \\
\text { message } \\
\text { customer }\end{array}$ & $\begin{array}{l}\text { - More often internal } \\
\text { briefing for create } \\
\text { new idea } \\
\text { - Intense } \\
\text { communication } \\
\text { with corporate } \\
\text { customer and } \\
\text { personal customer } \\
\text { - Coordination with } \\
\text { government and } \\
\text { media } \\
\text { Collaborate with } \\
\text { "generasi pesona } \\
\text { Indonesia" (tourism } \\
\text { community) }\end{array}$ & $\begin{array}{l}\text { Coordination } \\
\text { with } \\
\text { government } \\
\text { and media } \\
\text { More often } \\
\text { message } \\
\text { customer }\end{array}$ & \begin{tabular}{|l} 
- Intense \\
communication \\
with corporate \\
customer and \\
personal \\
customer \\
- Coordination \\
with government \\
and media \\
- Collaborate with \\
"generasi pesona \\
Indonesia" \\
(tourism \\
community)
\end{tabular} & $\begin{array}{l}\text { More often internal } \\
\text { briefing for create } \\
\text { idea } \\
\text { - Intense } \\
\text { communication with } \\
\text { corporate customer } \\
\text { and personal } \\
\text { customer } \\
\text { - Coordination with } \\
\text { government and } \\
\text { media } \\
\text { Collaborate with } \\
\text { "generasi pesona } \\
\text { Indonesia" (tourism } \\
\text { community) }\end{array}$ \\
\hline
\end{tabular}

(source: summary of interview)

Table 1 showed the comparison of PR hotels in Anyer. The results of this study showed that of the four roles, the role that has been conducted by the public relations in Anyer hotels are: 
1. Communicator. The PR role as a communication in the hotels of Anyer area is very important. For that, the PR officers are chosen not only based on the educational background, that is D-3 minimum, but also from their ability to communicate well. The goal of the role is to be able to form a positive public opinion of the hotels in Anyer area. Performing its role as a communicator, the PR officers at the hotels in Anyer area practice:

a) Internal briefing at least once every one to two weeks. The program was aimed to report any of the hotel's achievements within that one or two weeks, evaluate their strength, and brainstorm to bring up ideas in developing the hospitality business. The briefing is usually attended by all officers and representatives of the hotel manager/head.

b) Make a visit to the corporate customers. The visit usually includes hotel service offerings for companies or institutions (meetings, family gatherings, etc.) and for service evaluation.

c) Conducting visits or coordination with related parties such as government, community, or local media in the framework of the promotion of the hotel.

d) Disseminate short messages through SMS or WhatsApp to individual customers related to promo prices, as well as interesting events that will be held around Anyer beach.

2. Build relationships. The PR officers of the hotels in Anyer area foster relationships routinely by visiting the corporate customers and sending short messages to the individual customer.

3. The support of tourism. They do not play the role as the support of tourism in the organizational or corporate functions. They just play the role as hotel communicators.

4. Building a corporate image. The PR officers of the hotels in Anyer formed corporate images through the appearances and services at the hotel, as well as during the visit. The most important image is clean and comfortable. As the hotel representative, a PR officer is obliged to have a nice, clean, and tidy look. Good communication is also one of the skills that a PR officer must have. The role of the PR officers in forming a positive corporate image in the eyes of the hotel visitors with good appearance (clean and tidy) and good communication skills (polite and ethical) is what will leave a positive impression on the visitors of the hotels in Anyer area.

\section{The Strategy of Public Relations in Anyer After Tsunami}

After the tsunami, hotels in Anyer area experienced a very drastic decline in hotel guest visits. Usually, the occupancy rate reaches $85 \%-100 \%$ every weekend or long holiday, but post-tsunami, the maximum room occupancy only reacher $5 \%$. The achievement of the highest occupancy of the room is approximately $65 \%$ during the Lunar New Year long weekend. The price offered was deducted about 40\%$65 \%$ of the usual price. This requires hospitality management to work very hard to keep the hospitality operations running.

Strategies used in public relations as an effort to increase the occupancy of the hotel rooms in Anyer area is by improving relations with both the internal and external parties of the company, including:

\section{Internal Relations Strategy}


Internal Briefing at least every one to two weeks. The program was aimed to report any of the hotel's achievements within that one or two weeks, evaluate their strength, and brainstorm to bring up ideas in developing the hospitality business. The briefing is usually attended by all officers and representatives of the hotel manager/head.

After the tsunami, the hotel business decreased drastically, resulting in dissolving some employees such as the receptionists, housekeepers, and restaurant waiters. It impacted to some employees' motivations who are still surviving in these hotels. The post-tsunami internal Briefing was carried out more often to motivate the employees who survived.

\section{External Relations Strategy}

\section{a. Community Relationship}

Generasi Pesona Indonesia or known as GENPI became a partner who provides tremendous support after the tsunami. To recover from the tsunami impact, GENPI of Banten Province and GENPI of Serang conducted a lot of promotion through social media and through its network of communities. Events held by the provincial and district governments can be promoted well through GENPI community.

b. Government Relationship

The government became one of the biggest supporters in the process of tourism recovery and the effort to increase the level of visit to the hotels of Anyer. Various events were held after the tsunami from 2018 to present to increase the visit and hotel occupancy rate in Anyer. This involves not only the local government (Banten and Serang), but also the central government (the Ministry of Tourism of Indonesia) that held several events and directly visited tourism areas affected by the tsunami.

The Tourism Minister of Indonesia Arief Yahya reveals three recovery strategies of the Sunda Strait tourism sector which include the recovery of human resources, advising, and affected destinations. The events targeted by the Ministry of Tourism that cover 49 activities which include the recovery of the affected destinations are 16 activities, 19 marketing and promotional recovery activities, and 14 activities for institutional or human resources recovery. The budget funds for these activities are about 15 billion rupiahs.

The Tourism Office of Banten Province with GENPI, local media, and also supported by the central and district governments cooperated to restore Anyer tourism and other places affected by the tsunami. The Musabaqoh Tilawati Quran (MTQ) event has been routinely implemented in Serang. MTQ Serang was initially held in Pabuaran, but to increase the visit in Anyer, the program was transferred to Anyer and Cinangka. In addition to the MTQ event, the government of Serang also held various events, including Color Run, Trail, Silat Kaserangan Festival, Sunda Strait Fishing, to the birds chirping competitions.

\section{c. Customer Relationship}

There are quite a lot of corporate customers who no longer use hospitality services around Anyer for security reasons. In this case, the public relation continues to visit corporate customers and promote through short messages to individual customers. However, to increase and foster the trust of corporate and individual customers, PR officers are supported by the community and government as external parties that also convince the customers. 


\section{d. Media Relationship}

\#SelatSundaAman became a quite popular hashtag in the media as an effort to increase the number of room occupancy in the hotels in Anyer. It is one of the efforts through both social media as well as local media in giving support to the hospitality tourism business in Anyer after the tsunami. These strategies are implemented quite well by the PR of the hotels in Anyer. However, the business has not produced maximum results. After the tsunami, the occupancy rates of the hotels in Anyer only range at $65 \%$ in holiday seasons and only around 5\% on any other day. It is unlike the pre-tsunami days which usually reached $100 \%$ during holiday periods, and can be above $50 \%$ on ordinary days.

\section{Conclusion}

Out of four public relation roles, hotel PR in Anyer has performed three roles. The PR officers in the hotels in Anyer post-tsunami played their part good enough. The roles of public relations in the hotels of Anyer are: (1) a communicator, (2) to build a relationship, (3) to form a corporate image. Public relation officers at the hotels in Anyer does not perform as tourism support. Hotels PR just concerns to returning guests of hotels. The strategy made by the PR officers of the hotels in Anyer returning guest of hotels include: (1) internal relations strategy (employee relationship and manager relationship), and (2) external relations strategy (community relationship, customer relationship, media relationship, government relationship).

\section{Suggestion}

PR has a very important role in shaping the image of a tourist attraction. However, the occurrence of natural disasters is very different from other factors that may affect the number of visitors in tourist spots. Therefore, it requires harder efforts from both the management of the hotel and the stakeholders such as the community, media, and government in providing support to restore the tourist attractions.

\section{References}

Kurniasari, Nani. (2017). Strategi Penanganan Krisis Kepariwisataan dalam Kebijakan Badan Nasional Penanggulangan Bencana (BNPB). Vol.10, pp 177-189.

Musyaroffah, M. (2018). Peran Humas dalam Pengembangan Pendidikan Tinggi. Jurnal Idaarah. Vol.2.

Nguyen, D., N., \& Imamura, F. (2017). In Recovering from Catastrophic Disaster in Asia Community, Environment and Disaster Risk Management Vol 18, 37 - 59. https://doi.org/10.1108/S2040726220160000018001

Prideaux, B., Coghlan., A., \& Falco-Mammone., F. (2008). Post Crisis recovery. Journal of Travel \& Tourism Marketing. 23 (2-4), 163-174.

Rakhmat, Jalaludin. (2009). Metode Penelitian Komunikasi. Bandung: PT.Remaja Rosdakarya.

Ruslan, Rosady. (1998). Praktik dan Solusi Public Relations dalam Situasi Krisis dan Pemulihan Citra. Jakarta: Ghalia Indonesia. 
Rusli, Irjan, dan Ariska Rudyanto. (2010). Pemodelan Tsunami Sebagai Bahan Mitigasi Bencana Studi Kasus Sumenep dan Kepulauannya. Vol.2, pp 164-182.

Scott, N., Laws, E., \& Prideaux, B. (2008). Tourism crises and marketing recovery strategies. Journal of Travel \& Tourism Marketing, 23 (2-4), 1 -13

Sulistyawati, A., S., \& Pertiwi, P., R. (2018). Peranan Public Relations dalam Meningkatkan Tingkat Hunian Kamar di Hotel Kawasan ITDC Nusa Dua Bali Pasca Erupsi Gunung. Jurnal Kepariwisataan dan Hospitalitas. Vol. 2. (136-143).

Walters, G., \& Mair, J. (2012). The effectiveness of post-disaster recovery marketing message: The case of the 2009 Australian Bushfires. Journal of Travel \& Tourism Marketing, 29, 87 - 103.

Wilopo, K., K., \& Hakim, L. (2017). Strategi Pengembangan Destinasi Pariwisata Budaya. Jurnal Administrasi Bisnis. Vol.41. (56-65).

Zaenuri, Muchamad. (2014). Mengelola Pariwisata-Bencana: Perlunya Perubahan Paradigma Pengelolaan Pariswisata dari Adaptive Governance Menuju Collaborative Governance. Vol. XXXVI, pp 157168. 